\author{
Piotr Szafiński* \\ ORCID: 0000-0001-5483-7242 \\ Uniwersytet Wrocławski
}

https://doi.org/10.19195/1733-5779.33.16

\title{
Certyfikat Fair Trade jako narzędzie promocji
}

JEL Classification: F1, F14, M3

Słowa kluczowe: sprawiedliwy handel, ubóstwo, równość, promocja

Keywords: Fair Trade, poverty, equality, promotion

\begin{abstract}
Abstrakt: W celu walki z ubóstwem powołano do życia międzynarodowy ruch Fair Trade. Konsumenci, kupując produkty certyfikowane logiem Sprawiedliwego Handlu, pośrednio biorą udział w akcji charytatywnej. Jako że znak Fair Trade odgrywa istotną rolę wobec państw ubogich oraz ma być gwarancją jakości produktu, celem artykułu jest określenie, czy może on być skutecznie wykorzystywany jako narzędzie promocji. Praca powstała na podstawie źródeł literaturowych oraz badań własnych, przeprowadzonych w formie wywiadu pogłębionego. W obszarze zainteresowań znaleźli się klienci jednego z sieciowych sklepów specjalistycznych we Wrocławiu. Wyniki badań wskazują, że obecnie certyfikat nie może być skutecznym narzędziem promocji, jednak przy obserwowanym wzroście świadomości konsumentów można go w przyszłości wykorzystywać jako element marketingu.
\end{abstract}

\section{Fair Trade certificate as a promotion tool}

Abstract: In order to reduce poverty, the international Fair Trade movement was established. Consumers buying products certified with the Fair Trade logo indirectly participate in a charity event. Considering that the Fair Trade mark plays an important role towards poor countries and is a guarantee of product quality, the purpose of the article is to determine whether it can be effectively used as a promotion tool. The work was based on literature sources and the author's own research conducted in the form of in-depth interview. The area of interest includes clients of one of the specialist chain stores in Wrocław. Research results indicate that the certificate cannot currently be an effective promotion tool, but with the observed increase in consumer awareness, it can be used in the future as an element of marketing.

\footnotetext{
* Opiekun naukowy (Scientific Tutor) — dr Małgorzata Wachowska
} 


\section{Wstęp}

Powszechnie uważa się, że ruch Fair Trade przyczynia się do poprawy poziomu życia najuboższych społeczeństw na świecie, co wynika z tego, że konsument, kupując produkty oznaczone certyfikatem Fair Trade, nie płaci jedynie za sam produkt, ale niejako bierze również udział w akcji charytatywnej. Produkty z certyfikatem Fair Trade są bowiem droższe aniżeli analogiczne bez takiego oznaczenia, a swoista nadwyżka trafia (przynajmniej w założeniu) do producentów z najuboższych państw świata, zrzeszonych w ruchu Fair Trade.

Biorąc pod uwagę znaczenie sprzedaży tych produktów dla słabo rozwiniętych gospodarczo państw oraz możliwość niesienia bezinteresownej pomocy przez każdego konsumenta, autor jako cel artykułu postawił odpowiedź na pytanie, czy w polskich warunkach certyfikat Fair Trade ma potencjał, by stać się skutecznym narzędziem promocyjnym. W szczególności punktem zainteresowania autora jest rozstrzygnięcie dwóch kwestii. Po pierwsze, czy konsumentom znany jest ruch Fair Trade. Po drugie, czy znajomość tej idei ma wpływ na decyzje nabywców odnośnie do dokonywanych wyborów zakupowych. W tekście przyjmuje się założenie, że w im większym stopniu konsumenci znają ideę Fair Trade i im bardziej decydujący wpływ wywiera ona na podejmowane wybory zakupowe, tym większy jest potencjał certyfikowania produktów oznaczeniem Sprawiedliwego Handlu jako skutecznego narzędzia promocji.

Niniejszy artykuł uzupełnia dotychczasową literaturę dotyczącą problematyki Fair Trade oraz jego znaczenia podczas dokonywania wyborów zakupowych przez konsumentów. W pracy wykorzystano metodę wywiadu pogłębionego przeprowadzonego na grupie klientów jednego ze sklepów specjalistycznych we Wrocławiu. Badanie zostało przeprowadzone w okresie od stycznia do marca 2020 roku. Większość istniejących analiz dotyczących Polski skupia się na badaniach ankietowych, których wyniki wprawdzie dają się uogólnić na całą populację, jednakże podczas tego typu badań można pominąć wiele szczegółowych, interesujących $\mathrm{i}$ istotnych kwestii, które mogą okazać się kluczowe dla rozważanego problemu.

Pozostała część opracowania przedstawia się następująco: w punkcie pierwszym dokonano krótkiego przeglądu literatury z perspektywy znaczenia certyfikatu Fair Trade w kształtowaniu postaw konsumentów; w punkcie drugim opisana została metoda badań zastosowana w tym tekście; wyniki badań przedstawiono w punkcie trzecim, a w końcowym główne wnioski.

\section{Certyfikat Fair Trade w kształtowaniu postaw konsumentów - przegląd literatury}

\subsection{Geneza ruchu Fair Trade}

Ubóstwo jest niewątpliwe jednym z kluczowych problemów współczesnego świata. Kraje różnią się między sobą poziomem rozwoju gospodarczego, a co za 
tym idzie poziomem życia jego obywateli. Źródeł takiego stanu rzeczy można doszukiwać się na wielu płaszczyznach: od formy prowadzonej polityki przez rząd państwa po uwarunkowania geograficzne danego terytorium ${ }^{1}$. Dlatego podjęto próbę zniwelowania tego negatywnego zjawiska. Narzędziem realizacji tego celu było uruchomienie odpowiedniej platformy współpracy między państwami wysoko i słabo rozwiniętymi gospodarczo. Pierwszym krokiem było rozróżnienie, które państwa należy zaliczyć do danej grupy.

Świat od lat dzielił się na bogate kraje „Globalnej Północy” oraz biedne kraje „Globalnego Południa”. O tym, które państwa klasyfikują się do konkretnej grupy, nie świadczy jednak tylko położenie geograficzne. O kwestii podziału decyduje także popularny miernik makroekonomiczny stosowany do szacowania poziomu rozwoju gospodarczego - produkt krajowy brutto (PKB). Wyraża on w pieniądzu wartość dóbr i usług wytworzonych w danym kraju w określonym czasie ${ }^{2}$. Poziom PKB na osobę i poziom dobrobytu są mocno z sobą skorelowane i pozwalają łatwo określić, czy dane państwo należy do grupy krajów wysoko uprzemysłowionych, czy też ubogich lub dopiero się rozwijających ${ }^{3}$. Dzięki użyciu tego miernika mianem krajów „Globalnego Południa” określono większość państw leżących w Afryce, Ameryce Południowej i Środkowej oraz Azji.

Różnice dzielące bogatą Północ i ubogie Południe skutkowały powołaniem do życia ruchu Sprawiedliwego Handlu (Fair Trade) mającego za zadanie niwelowanie dysproporcji między tymi regionami. Współpraca pomiędzy kontynentami, jaką wspiera Fair Trade, jest niezbędna w celu przyszłego zrównania państw ubogich i bogatych pod względem poziomu rozwoju gospodarczego ${ }^{4}$. Proces ten wymaga czasu i mimo że państwa Południa cały czas odnotowują wzrost gospodarczy, w wielu z nich mieszkańcy wciąż żyją znacznie poniżej wszelkich standardów5. Siła robocza stanowi w tych państwach jeden z najcenniejszych zasobów. To jednak nie wystarczy, aby kraje te mogły gospodarczo rywalizować z innymi, lepiej rozwiniętymi. Dlatego kraje Północy ingerują w gospodarkę krajów Południa, aby te skuteczniej mogły walczyć z kryzysem wewnętrznym ${ }^{6}$.

${ }^{1}$ H. Dudek, I. Lisicka, Determinants of Poverty - Binary Logit Model with Interaction Terms Approach, Warszawa 2013, s. 65, 66.

2 D. Doniec, Produkt krajowy brutto, rachunki regionalne w 2015 r., Urząd Statystyczny w Katowicach, Katowice 2017, s. 14.

${ }^{3}$ M. Sulmicka, Polityka gospodarcza a wskaźnik rozwoju oraz ubóstwa społecznego, „Prace i Materiały Instytutu Rozwoju Gospodarczego SGH” 71, 2002, s. 101.

4 T.N. Srinivasan, Trade, Growth and Poverty Reduction, Commonwealth Secretariat, London 2009, s. 91.

5 J. Czerny, Moralny wymiar nierówności społecznych, Katowice 2013, s. 56.

${ }^{6}$ B. Baulch, Why Poverty Persist. Poverty Dynamics in Asia and Africa, Northampton 2011, s. 13. 


\subsection{Charakterystyka ruchu Fair Trade}

Nieoficjalnie początków Fair Trade można się doszukiwać pod koniec lat czterdziestych XX wieku w Stanach Zjednoczonych, kiedy to promowano kupno produktów od małych grup etnicznych w celu ich wsparcia w kryzysie spowodowanym powojenną dezintegracją systemu kolonialnego. Jednak oficjalne początki ruchu Fair Trade odnotowano w grudniu 2001 roku — wówczas została sformułowana jego definicja. Dokonały tego cztery główne organizacje zajmujące się tematyką sprawiedliwego handlu: Fairtrade Labelling Organizations International (FLO), International Federation for Alternative Trade (IFAT), Network of European Worldshops (NEWS!) oraz European Fair Trade Association (EFTA) tworzące wspólnie nieformalną platformę współpracy o nazwie „FINE” ". W świetle opracowanej przez te organizacje definicji ,sprawiedliwy handel” to partnerstwo, którego celem jest uzyskanie równości w handlu międzynarodowym.

Oprócz samej definicji określono także działania zmierzające do zrównoważonego rozwoju, takie jak oferowanie lepszych warunków handlowych oraz ochrona praw producentów i pracowników, szczególnie w biedniejszych krajach Południa. Z kolei zasady funkcjonowania określono w Karcie zasad Sprawiedliwego Handlu opracowanej w 2009 roku i zatwierdzonej przez Światową Organizację Sprawiedliwego Handlu (WFTO). Podstawową regułą jest stawianie człowieka ponad zyskiem. Ponadto organizacje Sprawiedliwego Handlu powinny dołożyć wszelkich starań, aby zwiększać świadomość i prowadzić kampanie na rzecz zmiany konwencjonalnych praktyk handlu międzynarodowego ${ }^{8}$. To oznacza, że ruch Fair Trade ma na celu budowanie sprawiedliwych i przykładnych relacji handlowych poprzez wzajemny szacunek pomiędzy biednymi producentami krajów Południa a konsumentami państw Północy. Przy podejmowaniu tych działań brane jest pod uwagę również poszanowanie praw człowieka oraz podstawowe zasady ochrony środowiska ${ }^{9}$. Dodatkowo idea Sprawiedliwego Handlu obejmuje wiele innych istotnych kwestii współczesnego świata, takich jak ochrona praw kobiet i dzieci czy unikanie żywności genetycznie zmodyfikowanej ${ }^{10}$.

Rozwój ruchu spowodował wymóg odpowiedniego certyfikowania produktów Sprawiedliwego Handlu. Na wielu towarach, takich jak na przykład kawa, kosmetyki, słodycze, napoje bezalkoholowe, ale też alkohol, można odnaleźć ujednolicone logo Fair Trade, które jest zastrzeżonym znakiem towarowym Unii

7 T. Makulski, Fair Trade, czyli sprawiedliwy handel - przewodnik, Gdynia 2015, s. 5.

8 World Fair Trade Organization, https://wfto.com/who-we-are\#defining-fair-trade (dostęp: 6.03.2020).

9 J. Rymarczyk, M. Domiter, W. Michalczyk, Integracja i kryzysy na lokalnych i globalnych rynkach we współczesnym świecie, Wrocław 2013, s. 268, 269.

${ }^{10}$ I. Grant, W.A. Kerr, Genetically modified organisms and trade rules: Identifying important challenges for the WTO, „World Economy” 26, 2003, nr 1, s. 29. 
Europejskiej ${ }^{11}$. Nadzór nad tym znakiem pełni organizacja FLO, która pilnuje przestrzegania zasad Sprawiedliwego Handlu i na tej podstawie wydaje zezwolenia na użytkowanie logotypu przez producentów ${ }^{12}$.

Mechanizm funkcjonowania ruchu Fair Trade jest oparty na założeniu, że konsument na rynku komercyjnym jest gotów zapłacić nieco więcej za produkt oznaczony certyfikatem niż za podobny towar. Ustalona na odpowiednim poziomie cena minimalna jest najważniejszym narzędziem polityki Sprawiedliwego Handlu, albowiem gwarantuje zysk dla producentów z krajów Południa niezależnie od kształtującej się sytuacji popytu i podaży na rynku ${ }^{13}$. Zasada partnerstwa handlowego oznacza w tym wypadku zgodę konsumentów z krajów dobrze rozwiniętych na daną cenę i pełną ich świadomość dokonywanego wyboru. Kupujący jest bowiem gotów wydać więcej w celu wsparcia akcji charytatywnej, której wszystkie cele i zasady potwierdza certyfikat na opakowaniu ${ }^{14}$. Niesienie pomocy biednym, życie $\mathrm{w}$ zgodzie $\mathrm{z}$ naturą oraz walka $\mathrm{z}$ dyskryminacją kobiet i dzieci to bez wątpienia poważne problemy współczesnego świata, z którymi należy się zmierzyć. Ponadto sam certyfikat nie oznacza jedynie przestrzegania wymienionych zasad, lecz jest także swego rodzaju gwarantem jakości produktu, co również uzasadnia wyższą cenę.

\subsection{Znaczenie certyfikatu Fair Trade — przegląd literatury}

Wielu naukowców na świecie zajmuje się tematyką sprawiedliwego handlu. Dotychczasowa literatura dotycząca problematyki Fair Trade skupia się głównie wokół tematu skuteczności ruchu z perspektywy zwalczania ubóstwa. W wielu artykułach i innych publikacjach naukowych podawana jest w wątpliwość sama ideologia sprawiedliwego handlu i jej skuteczność niesienia pomocy krajom Globalnego Południa. Taki problem opisuje M. Grącik-Zajączkowski ${ }^{15}$. Jednakże w literaturze zagranicznej podejmuje się również tematykę wpływu certyfikatu na zachowanie konsumenta i jego wybory zakupowe. Odbiorcy tworzą grupę niezwykle zróżnicowaną, a dodatkowo każdy kraj cechuje inna kultura, poziom świadomości społeczeństwa oraz preferencje zakupowe, wobec czego wyników nie można uogólnić na każdą populację. Taki problem badawczy podejmują E. Wang

11 J.E. Stiglitz, A. Charlton, Fair Trade For All: How Trade Can Promote Development, New York 2005, s. 211.

12 W. Patrzałek, Konsumpcja jako forma komunikacji społecznej. Nowe paradygmaty i konteksty badawcze, Wrocław 2015, s. 115.

13 J. Rymarczyk, M. Domiter, W. Michalczyk, op. cit., s. 269.

14 M. Radziukiewicz, Sprawiedliwy Handel na rzecz ograniczania ubóstwa w najbiedniejszych krajach, „Handel Wewnętrzny” 2013, nr 6, s. 26.

15 M. Grącik-Zajaczkowski, Fair trade: szansa czy zagrożenie dla rozwoju krajów Poludnia?, „Prace Naukowe Uniwersytetu Ekonomicznego we Wrocławiu” 315, 2013, nr 1, s. 267-276. 
Shih-Tse oraz Ch. Yu-Chen ${ }^{16}$. Pomiar dotyczący preferencji zakupowych w odniesieniu do ideologii Fair Trade został przeprowadzony na próbie 775 studentów Uniwersytetu Narodowego Chung Hsing w Tajwanie. Spośród ankietowanych 398 osób znało założenia i cel Sprawiedliwego Handlu, lecz nie zawsze kierowało się nimi podczas dokonywania wyborów zakupowych.

Natomiast o podejściu polskich konsumentów do ideologii ruchu Fair Trade wspomina M. Radziukiewicz ${ }^{17}$. Ankietowani określili, ile są w stanie dopłacić do produktu oznaczonego certyfikatem. Odnaleziono zależność między ceną produktu a gotowością do wydania większej sumy pieniędzy. W wypadku towarów, których cena oscyluje w okolicach 100 złotych, konsumenci w większości są gotowi wydać maksymalnie $20 \%$ więcej niż kwota podstawowa. Jeśli chodzi o produkty z niższych przedziałów cenowych, wartości te sięgały nawet $80 \%$ ceny wyjściowej. Wyniki te mogą oznaczać wciąż niską siłę nabywczą wynagrodzenia wśród społeczeństwa polskiego. W osobnym artykule badacz ten dokładniej zagłębia się $\mathrm{w}$ preferencje konsumentów ${ }^{18}$. Wyniki wskazują, że blisko dwa razy częściej nabywcami produktów oznaczonych logiem Fair Trade są kobiety, a najczęściej kupowanymi artykułami są używki, w tym kawa i herbata.

Badań preferencji konsumentów dotyczących produktów Fair Trade podjęli się również V. Andorfer i U. Liebe ${ }^{19}$. Udowodnili oni pozytywny odbiór ideologii Sprawiedliwego Handlu mimo wyższych cen oferowanych towarów. Większość respondentów skłonna była zapłacić więcej w celu wsparcia ideologii. Niekiedy wartości te sięgały nawet $50 \%$ ceny wyjściowej.

Zależność pomiędzy narodowością a wpływem na podejmowane wybory konsumenckie odnajduje A. Gillani, przeprowadzając badania na próbie 211 brytyjskich i 112 hinduskich konsumentów ${ }^{20}$. Wyniki jego analiz jednoznacznie wskazywały na korelację między pochodzeniem a świadomością dokonywanych decyzji zakupowych. U Brytyjczyków zaobserwowano wyższy poziom znajomości idei Fair Trade i to oni prezentowali większą chęć niesienia pomocy krajom Globalnego Południa.

16 E. Wang Shih-Tse, Ch. Yu-Chen, Effects of perceived justice of fair trade organizations on consumers' purchase intention toward fair trade products, „Journal of Retailing and Consumer Services" 50, 2019.

17 M. Radziukiewicz, op. cit.

18 M. Radziukiewicz, Zachowania i preferencje konsumentów produktów Fair Trade, „Handel Wewnętrzny" 2014, nr 3, s. 215-228.

19 V. Andorfer, U. Liebe, Research on fair trade consumption - A review, „Journal of Business Ethics" 106, 2012, nr 4, s. 415-435.

20 A. Gillani et al., The impact of proximity on consumer fair trade engagement and purchasing behavior: The moderating role of empathic concern and hypocrisy, „Journal of Business Ethics" 2019. 
Do podobnych wniosków doszedł R. Tamaki, analizując zachowania australijskich i japońskich konsumentów ${ }^{21}$. Ci pierwsi wykazali się większą znajomością ruchu Fair Trade niż Japończycy i to oni chętniej podejmowali działania charytatywne w postaci kupna produktów oznaczonych certyfikatem potwierdzającym założenia omawianej ideologii.

O skuteczności idei Fair Trade zapewnia E. Cummings ${ }^{22}$. Swoje badania przeprowadziła nie od strony konsumenta, lecz z punktu widzenia producentów. Z grupy 100 rolników z Ugandy należących i nienależących do ruchu Fair Trade znaczna większość uznających i prowadzących działania zgodne z ideologią potwierdziła, że cena jest uczciwa, i wyraziła swoje zadowolenie $\mathrm{z}$ otrzymywanego wynagrodzenia.

Zdanie E. Cunnings potwierdzili S. Imhof i A. Lee, którzy we wnioskach swoich badań jasno określili potencjał ideologii Fair Trade i jej skutecznej walki z ubóstwem i nierównościami na świecie, przy odpowiednim poziomie konkurencyjności produktów oznaczonych certyfikatem w porównaniu do towarów spoza ruchu Sprawiedliwego Handlu ${ }^{23}$. Wyniki tych badań podważył Ch. Estevez ${ }^{24}$. Zgodził się z dobrze sformułowanymi celami Sprawiedliwego Handlu, jednak po szczegółowej analizie rynku kawy w Boliwii stwierdził, że ideologia może być również zagrożeniem dla ubogich producentów. Głównym tego powodem jest wysoka cena produktów, ograniczone finansowanie oraz presje ekonomiczne związane z certyfikacją.

Niezwykle istotnym czynnikiem warunkującym sprzedaż produktów Sprawiedliwego Handlu jest reklama, co udowadnia badanie przeprowadzone przez C. Zerbiniego, D.T. Vergura i B. Luceri ${ }^{25}$. We Włoszech analizą objęto 200 osób, a badanie podzielono na dwa etapy. Początkowo ankietowani zaznaczali odpowiedzi wedle własnych preferencji. Następnie zostali zapoznani z blokiem reklamowym promującym ideę Sprawiedliwego Handlu. Wyniki eksperymentu udowodniły skuteczność prospołecznej kampanii marketingowej i gotowość do zakupu produktów Fair Trade.

W Polsce wciąż brakuje szczegółowych badań dotyczących znajomości ruchu Sprawiedliwego Handlu i jego wpływu na wybory zakupowe, w tym w kontekście skuteczności certyfikatu Fair Trade jako narzędzia oddziaływania na nabywcę.

21 R. Tamaki, Consumers' Perception of Fair Trade Coffee in Australia and Japan, Perth 2013.

22 E. Cummings, Fair Trade or Fake Trade? Specialty coffee certifications and development in Uganda, „Independent Study Project (ISP) Collection” 2172, 2015, https://digitalcollections.sit. edu/isp_collection/2172 (dostęp: 6.03.2020).

23 S. Imhof, A. Lee, Assessing the potential of Fair Trade for poverty reduction and conflict prevention: A case study of Bolivian coffee producers, „Schweizer Staatssekretariat for Wirtschaft" 2007.

${ }^{24}$ Ch. Estevez, A Market Study of Organic and Fair Trade Coffee in Bolivia, Miami 2015.

25 C. Zerbini, D.T. Vergura, B. Luceri, How fair-trade claims and emotional empathy affect the consumer's propensity to buy fair chocolate?, „British Food Journal” 121, 2019, nr 7. 
Same analizy ankietowe, choć dają się uogólnić, nie odzwierciedlają bowiem pełnej sytuacji rynkowej. Na ich podstawie nie można więc jednoznacznie określić skuteczności certyfikowania produktów logiem Fair Trade jako decydującego czynnika podczas dokonywania zakupów przez konsumentów. Świadomość nabywców co do podejmowanych decyzji zakupowych w ostatnim czasie bardzo intensywnie wzrasta. Dzieje się tak chociażby z powodu współcześnie panującej mody na żywność ekologiczną czy też tendencji niesienia pomocy poprzez zakup odpowiednich towarów. Konsumenci coraz większą uwagę skupiają na składzie i pochodzeniu produktu oraz często podkreślanych na etykiecie akcjach charytatywnych związanych z ich zakupem. Wobec tego uzasadnione byłoby określenie potencjału ideologii Fair Trade jako skutecznego narzędzia promocji. Istotnym uzupełnieniem dotychczasowej literatury oraz istniejących już badań ilościowych mogą być dodatkowe badania jakościowe szczegółowo opisujące stosunek konsumentów do certyfikatu Sprawiedliwego Handlu na produktach.

\section{Zakres i metoda badań}

Podstawą analizy są badania jakościowe przeprowadzone w formie wywiadu pogłębionego w okresie od stycznia do marca 2020 roku. Głównym celem badań było zgromadzenie szczegółowych informacji na temat znajomości ruchu Fair Trade oraz jego wpływu na wybory zakupowe podejmowane przez konsumentów, a tym samym odpowiedź na pytanie, czy certyfikat Fair Trade może być skutecznym narzędziem promocji.

Wywiad podzielono na dwa etapy. W pierwszej części pytano konsumentów o ideologię Fair Trade. Badanie koncentrowało się wokół ogólnej wiedzy na temat sprawiedliwego handlu oraz jego założeń. Podstawowe pytanie dotyczyło rozpoznawalności idei. W tym celu pytano o znajomość ruchu Fair Trade lub prezentowano jego znak graficzny, a klienci odpowiadali na pytania mające na celu określenie poziomu wiedzy na temat ideologii, certyfikowania produktów i znaczenia ruchu dla krajów ubogich.

Druga część wywiadu była prowadzona w formie swobodnej dyskusji poruszającej szczegółowo temat sprawiedliwego handlu oraz jego wpływu na wybory zakupowe w życiu codziennym. Respondenci dzielili się osobistymi opiniami dotyczącymi współczesnego problemu ubóstwa na świecie oraz możliwymi sposobami przeciwdziałania temu zjawisku. Przedstawiali własne zdanie dotyczące oceny skuteczności ideologii Fair Trade. Podstawowym zadaniem prowadzonej rozmowy było określenie poziomu istotności certyfikatu Sprawiedliwego Handlu oraz jego wpływu na dokonywane wybory zakupowe. Z kolei respondenci, którzy w pierwszej części badania na pytanie o znajomość ruchu Fair Trade odpowiedzieli przecząco, zostali przede wszystkim zapoznani z ideologią i głównymi jej celami. W tym wypadku rozmowa miała na celu poznanie możliwych powodów 
nieznajomości ruchu Sprawiedliwego Handlu oraz określenie stosunku uczestnika badania do tego typu akcji charytatywnych. W wypadku obu grup respondentów dyskutowano także na temat czynników, które mają największy wpływ na wybór produktów.

W badaniach wzięli udział klienci jednego ze sklepów specjalistycznych we Wrocławiu, zajmujących się sprzedażą alkoholi z całego świata, głównie win. Dobór próby miał na celu jej jak największe zróżnicowanie. Uczestnikami badania były kobiety i mężczyźni w różnym wieku. Podczas prowadzonego wywiadu zadawano pytania dotyczące wykonywanego zawodu, stanu cywilnego oraz poziomu wykształcenia. W celu doprecyzowania próby dokładnie obserwowano zachowanie klientów, a także wzrokowo, po analizie ubioru, biżuterii i kupowanych produktów, oceniano stan majątkowy.

\section{Wyniki badań}

Odpowiedzi respondentów okazały się bardzo zróżnicowane. Spośród badanych średnio co trzecia osoba słyszała o ruchu Fair Trade lub przynajmniej kojarzyła znak graficzny. Jednak nie każdy z tej grupy umiał przedstawić podstawowe założenia, to znaczy opisać, czym jest sprawiedliwy handel i jaki cel mu przyświeca. Biorąc pod uwagę ogólne wyniki, należy stwierdzić, że znacznie częściej wiedzę na temat ruchu prezentowały kobiety. Największą znajomość ideologii wykazała także młodzież w wieku od 18 do 29 lat. Z kolei pośród osób powyżej 50. roku życia wiedza ta była znikoma.

Analizując wypowiedzi respondentów, można zauważyć pewną zależność między posiadanym majątkiem a poziomem informacji na temat ruchu wspierającego kraje ubogie. Największy odsetek zorientowanych w ideologii Fair Trade stanowiły osoby określone jako zamożne lub średniozamożne.

Podczas przeprowadzania wywiadu zauważono także wiele innych istotnych kwestii. Sporą część osób, które wykazały się wiedzą na temat sprawiedliwego handlu, tworzyli klienci dbający o środowisko naturalne. Osoby te rezygnowały z kupna foliowych reklamówek, zastępując je własnymi, bawełnianymi. Dużą wagę przywiązywały również do poszukiwania win ekologicznych, w których sztuczne nawozy zostały zastąpione naturalnymi zamiennikami, czego potwierdzeniem jest unijny certyfikat ekologiczny. Grupa osób aktywnie podejmująca działania w celu poprawy warunków środowiska naturalnego najczęściej określała znak Fair Trade na produktach jako istotny podczas dokonywania wyborów zakupowych. Przykładem może być zamężna klientka, w wieku około 28 lat, ubrana wyjątkowo elegancko, z drogim zegarkiem na ręce, która zrezygnowała z foliowej reklamówki, mówiąc, że dba o środowisko. Doskonale znała założenia ruchu i na pytanie o istotność certyfikatu odpowiedziała: 
Moja ulubiona kawa ma znak Fair Trade. Jest on dla mnie istotny i staram się kupować również inne produkty oznaczone tym znakiem.

Z kolei wiele osób znających ideologię sprawiedliwego handlu, jednak mniej zaangażowanych w działania ekologiczne, określało certyfikat jako znacznie mniej istotny podczas wyboru produktów. Jeden z zamożnych respondentów, w wieku około 33 lat, prowadzący własną działalność gospodarczą i kupujący wino z wysokiej półki cenowej, tak określił swoją decyzję:

Jeśli na półce będzie stał produkt z oznaczeniem Fair Trade i bez oznaczenia, to wybiorę ten certyfikowany. Jednak nie zwracam na to szczególnej uwagi i nie jest to mój priorytet podczas robienia zakupów.

Podobne podejście prezentowało wielu innych klientów.

Natomiast wśród osób nieznających ruchu Sprawiedliwego Handlu zdania na temat tego typu akcji charytatywnych były podzielone. Większość klientów po krótkim przedstawieniu i wyjaśnieniu najważniejszych założeń ruchu przedstawiła jednak pozytywne podejście do ideologii i zainteresowanie nią. Potwierdzeniem takiej postawy mogą być słowa mężczyzny w wieku około 55 lat, kupującego alkohol ze średniej półki cenowej, ubranego schludnie i klasycznie:

Bardzo ciekawa kampania, niestety nieznana mi jak dotąd. Z ciekawości sprawdzę w domu, czy nie mam przypadkiem produktów z takim logo.

Wielu respondentów przyznało, że nie zna idei, ponieważ nigdy o niej nie słyszało, a bardzo chętnie braliby udział w pomocy w takiej formie. Badani wielokrotnie odnajdowali przyczynę nieznajomości ruchu w słabym marketingu i wciąż małej popularności tego typu przedsięwzięć w naszym kraju. Przykładem może być wypowiedź jednego z klientów, w wieku około 35 lat, pracującego jako doradca klienta w popularnym sklepie odzieżowym, o czym świadczył jego ubiór firmowy i identyfikator. Po wcześniejszym zapoznaniu z logiem Fair Trade stwierdził:

Kojarzę skądś ten znak. Możliwe, że nawet kupowałem takie produkty. Ale szczerze mówiąc, nawet nie wiedziałem, co on oznacza.

Jego słowa potwierdziła inna respondentka, w wieku około 40 lat, kupująca wino w umiarkowanym przedziale cenowym (30-40 zł), w towarzystwie nastoletniego syna:

Założenia brzmią naprawdę pięknie. Nie wspierałam akcji, bo skąd miałam ją znać? Nigdy nie widziałam żadnej reklamy, żaden sprzedawca nie wspomniał mi o tym, a na małe logo na produkcie nawet nie zwracałam uwagi.

Spory odsetek zainteresowanych stanowiły osoby prowadzące zdrowy tryb życia (chodzące na siłownię, sprawdzające skład kupowanych produktów), dla których certyfikat Fair Trade oznaczał również gwarancję jakości produktu, chociażby przez unikanie żywności genetycznie zmodyfikowanej. 
Jednocześnie jednak część klientów nie wykazała poparcia dla ideologii Sprawiedliwego Handlu. Najczęściej było to umotywowane brakiem zaufania do tego typu akcji, co potwierdził jeden z respondentów, w wieku około 50 lat, wykonujący zawód nauczyciela:

Wspomagałem kiedyś podobnego typu działania, które finalnie okazały się zwykłym oszustwem stworzonym jedynie w celu polepszenia wizerunku marketingowego produktu.

To spowodowało jego awersję do wszelkiej pomocy wykonywanej w formie pośredniej, na przykład przez zakup określonych produktów wspierających cele charytatywne. O braku popularności ideologii Sprawiedliwego Handlu w Polsce i niskim poziomie świadomości może świadczyć również to, że jeden z respondentów poinformował, że pracuje w sklepie z żywnością, a mimo to o ruchu nigdy nie słyszał. Po późniejszej analizie asortymentu tego sklepu okazało się, że w ofercie znajdują się także produkty oznaczone certyfikatem Fair Trade.

Uczestników badania pytano również o czynniki, jakimi kierują się podczas dokonywania wyborów zakupowych. Odpowiedzi w większości były zgodne, niezależnie od wieku czy stanu majątkowego ankietowanych. Klienci najczęściej uznawali jakość produktu za decydujący element kupowanego towaru. Wielokrotnie pojawiał się także wątek ceny jako czynnika decydującego o wyborze. Jednak z reguły był on mniej istotny niż jakość, co podsumowuje wypowiedź jednej z klientek w średnim wieku, średniozamożnej, o czym mógł świadczyć klasyczny ubiór i kupowany produkt ze średniej półki cenowej:

Cena jest ważna podczas wyboru. Natomiast zawsze w pierwszej kolejności kieruję się jakością produktu. Wolę wydać troszkę więcej, niż kupować byle jaki produkt.

Oprócz wspomnianych odpowiedzi klienci wymieniali również skład i markę produktu, dotychczasowe przyzwyczajenia oraz rekomendacje znajomych. Czynniki te jednak odgrywały zwykle rolę drugorzędną.

\section{Zakończenie}

W Polsce wciąż nie wykorzystuje się certyfikatu Fair Trade do promowania produktów, a sprzedawcy, którzy mają tego typu asortyment, albo o tym nie wiedzą, albo nie sygnalizują tego swym klientom. Jest to trochę zaskakujące, zwłaszcza w obliczu tego, że Polacy coraz częściej podejmują działania mające na celu wszelkiego rodzaju pomoc: kobietom żyjącym w krajach, w których ogranicza się ich wolność, głodującym dzieciom z państw afrykańskich, chorym na nowotwory, ginącym gatunkom dzikich zwierząt, maltretowanym zwierzętom domowym, a także przeznaczonym do wycinki lasom. Dodatkowo od dłuższego czasu w polskim społeczeństwie zauważalna jest tendencja do życia zgodnie z ideami ekologicznymi, promowania zdrowego trybu życia itp. Zastanawiające jest zatem, że przedstawiciele biznesu, którzy są nastawieni przede wszystkim na osiąga- 
nie zysków, nie wykorzystują w swych kampaniach promocyjnych certyfikatu Fair Trade, który wręcz idealnie wpisuje się w trendy panujące obecnie w Polsce. W świetle tego stwierdzenia pytanie, czy w warunkach polskich certyfikat Fair Trade może być skutecznym narzędziem promocji, wydaje się szczególnie ważne.

Niestety wyniki przeprowadzonych badań nie odnajdują istotnej zależności między certyfikowaniem produktów logiem Fair Trade a dokonywanymi przez klientów wyborami zakupowymi. Mimo że ruch swoim zasięgiem obejmuje już prawie cały świat, a jego ideologia niesie z sobą wiele korzyści, respondenci w większości nie wykazali się znajomością akcji i jej podstawowych założeń. Poziom rozpoznawalności znaku Fair Trade w Polsce wciąż nie jest tak wysoki, aby producenci mogli wykorzystywać go w celu zwiększenia wyników sprzedaży. Dodatkowo nie zawsze pozytywna postawa wobec produktów oznaczonych tym znakiem znajdowała odzwierciedlenie w rzeczywistych wyborach rynkowych. Jedynie niewielki odsetek klientów, w dużym stopniu zaangażowanych w cele charytatywne i proekologiczne, kieruje się certyfikatem Sprawiedliwego Handlu podczas robienia zakupów.

Wyniki badań wskazują jednak na coraz większy wzrost świadomości konsumentów podczas dokonywania wyborów zakupowych. Głównym czynnikiem wpływającym na decyzję o zakupie produktu jest nie cena, lecz jakość, co pozwala sądzić, że w przyszłości logo Fair Trade ma szansę stać się skutecznym narzędziem promocji. Klient godzi się bowiem płacić więcej za dany towar w celu uzyskania gwarancji jakości produktu oraz dodatkowego wsparcia działań charytatywnych. Ponadto w ostatnich latach (o czym już wspomniano) zaobserwowano rosnącą tendencję do niesienia pomocy oraz walki z dyskryminacją rasową i płciową. Coraz częściej konsumenci podejmują też różnego rodzaju działania proekologiczne mające na celu ochronę środowiska naturalnego, takie jak rezygnacja $\mathrm{z}$ foliowych reklamówek czy plastikowych słomek. Te czynniki również mogą mieć znaczny wpływ na zwiększenie popularności ruchu Fair Trade w Polsce, a co za tym idzie wykorzystywania go w celach promocyjnych. Potwierdzeniem tego stanowiska może być zainteresowanie klientów ideologiami, o których dowiedzieli się dopiero podczas przeprowadzanego badania. Idąc tym tropem, należy uznać, że przy odpowiednim spopularyzowaniu ruchu Fair Trade jego certyfikat mógłby stać się skutecznym narzędziem marketingu przedsiębiorstw.

\section{Bibliografia}

Andorfer V., Liebe U., Research on fair trade consumption - A review, ,Journal of Business Ethics” 106, 2012, nr 4.

Baulch B., Why Poverty Persist. Poverty Dynamics in Asia and Africa, Northampton 2011.

Cummings E., Fair Trade or Fake Trade? Specialty coffee certifications and development in Ugan$d a$, „Independent Study Project (ISP) Collection” 2172, 2015, https://digitalcollections.sit.edu/ isp_collection/2172. 
Czerny J., Moralny wymiar nierówności społecznych, Katowice 2013.

Doniec D., Produkt krajowy brutto, rachunki regionalne w 2015 r., Urząd Statystyczny w Katowicach, Katowice 2017.

Dudek H., Lisicka I., Determinants of Poverty - Binary Logit Model with Interaction Terms Approach, Warszawa 2013.

Estevez Ch., A Market Study of Organic and Fair Trade Coffee in Bolivia, Miami 2015.

Gillani A., Kutaula S., Leonidou L.C., Christodoulides P., The impact of proximity on consumer fair trade engagement and purchasing behavior: The moderating role of empathic concern and hypocrisy, „Journal of Business Ethics” 2019.

Grant I., Kerr W.A., Genetically modified organisms and trade rules: Identifying important challenges for the WTO, „World Economy” 26, 2003, nr 1.

Grącik-Zajaczkowski M., Fair trade: szansa czy zagrożenie dla rozwoju krajów Południa?, „Prace Naukowe Uniwersytetu Ekonomicznego we Wrocławiu" 315, 2013, nr 1.

Imhof S., Lee A., Assessing the potential of Fair Trade for poverty reduction and conflict prevention: A case study of Bolivian coffee producers, „Schweizer Staatssekretariat for Wirtschaft” 2007.

Makulski T., Fair Trade, czyli sprawiedliwy handel - przewodnik, Gdynia 2015.

Patrzałek W., Konsumpcja jako forma komunikacji społecznej. Nowe paradygmaty $i$ konteksty badawcze, Wrocław 2015.

Radziukiewicz M., Sprawiedliwy Handel na rzecz ograniczania ubóstwa w najbiedniejszych krajach, „Handel Wewnętrzny” 2013, nr 6.

Radziukiewicz M., Zachowania i preferencje konsumentów produktów Fair Trade, „Handel Wewnętrzny" 2014, nr 3.

Rymarczyk J., Domiter M., Michalczyk W., Integracja i kryzysy na lokalnych i globalnych rynkach we wspótczesnym świecie, Wrocław 2013.

Srinivasan T.N., Trade, Growth and Poverty Reduction, Commonwealth Secretariat, London 2009.

Stiglitz J.E., Charlton A., Fair Trade for All: How Trade Can Promote Development, New York 2005.

Sulmicka M., Polityka gospodarcza a wskaźnik rozwoju oraz ubóstwa społecznego, „Prace i Materiały Instytutu Rozwoju Gospodarczego SGH” 71, 2002.

Tamaki R., Consumers' Perception of Fair Trade Coffee in Australia and Japan, Perth 2013.

Wang Shih-Tse E., Yu-Chen Ch., Effects of perceived justice of fair trade organizations on consumers' purchase intention toward fair trade products, „Journal of Retailing and Consumer Services" 50, 2019.

Zerbini C., Vergura D.T., Luceri B., How fair-trade claims and emotional empathy affect the consumer's propensity to buy fair chocolate?, „British Food Journal” 121, 2019, nr 7.

\section{Źródła internetowe}

World Fair Trade Organization, https://wfto.com/who-we-are\#defining-fair-trade.

Studenckie Prace Prawnicze, Administratywistyczne

i Ekonomiczne 33, 2020

(C) for this edition by CNS 